\title{
Journal of Ventilation
}

Volume 12 Number 1

ISSN $1473-3315$

June 2013

\section{Contents}

Correlation of Particulate Matter with Airborne Fungi in Schools in Greece Dortzas PV. Kapsanaki-Gotsi E. Assimakopoulos MN and Santamouris M

The Effect of Party Wall Permeability on Estimations of Infiltration from Air Leakage

Jones B Das P. Chalabi Z. Davies M. Hamiton I. Lowe R. Milner J.

Ridey I. Shrubsole C and Wilkanson P

Multiple Flow Regmes in Stack Ventlation of Multi-Storey Atrium Buildings Acred $A$ and Hunt GR

Numerical Study of a Vertical Channel Heated from Below to Enhance Natural Ventilation in a Residential Building

Coppi M Quintino A and Salata F

Computational Analysis of Wind-Driven Natural Ventilation In a Two Sided Rectangular Wind Catcher

M Hossein Ghedin, N Lukman. N Ibrahım and Mohd Fand Mohamed

Measurements and Numerical Simulation of the Gas-Solid Flow Generated by Machining Operation

Talnout F, Belut E, Oesterle B. Mikolajczak AT and Fontaine JR

PIV Measurements of Air Distribution in a Reduced-Scale Model - 


\section{Editorial Board}

Prof. Francis Allard (LEPTIAB, Université de La Rochelle, France);

Prof. Haxim Awbi (School of Construction Management and Engueering, Unversty of Reading, UK);

Prof. Malcolm Cook (Dept of Crvil and Btalding Engmeerng, Loughborough University, Leicester. UK);

Michael Donn (Centre for Bualding Perfonmance Research, Victona Unversity, Wellington New Zealand);

Dr. Rodger Edwards (Dept. of Building Engneerng, UMIST, UK);

Dr. David Etheridge (Unversity of Nottugham, UK):

Prof. Ing. Gian Vincenzo Fracastoro (Dipartimento di Energetica Politecnico di Torino, Italy):

Prof. Fariborz Haghighat (Depr. of Building, Crusl and Ervironmental Eng, Concordia Unrversity, Canada);

Prof. Per Heiselberg (Hybrid Ventilation Centre, Aalborg University, Dennank);

Dr. Gary Hunt Department of Engmeenng, Unversty of Cambradge, Cambradge CB2 IPZ, UK:

Prof. Yi Jiang (Dept. of Bulding Scrence \& Technology Tsinghua Unversity, China);

Prof. Miroslav Jicha (Faculty of Mechanical Engineering, Bmo Unwersity of Technology, Czech Republic);

Prof. Shinsuke Kato (Industrial Institute of Science, University of Tokyo, Japan);

Prof. Joseph Khedari (Rattanals ain Coll for Sust Energy \& Env, Raymangada UnN of Tech Rattanakosm. That andi);

Prof. Maria Kolokotroni (Bnutel University, UK);

Prof. Baizhan Li (Faculty of Unbor Construction and Environmertal Engineering Chongging Unvers dy, Chna);

Dr. Yugue Li (Unversity of Hong Kong, Chna);

Dr. Alfred Moser (Science Sensces Alfred Maser, Winterthur, Switzeriand);

Prof. Tadj Oreszczyn (Bartiett Sichool of Gradiate Studtes, Untwersity Coliege, Londion. UK);

Prof. Claude-Alain Roulet (Ecole Pobrtechnique Féderale de Lausamne, Swiss Fed. Inst. of Technology);

Prof. Mats Sandberg (Indioor Environment and Ventil ation, Dept of the Bualt Envirorment, HIG, Gavie, Sweden);

Prof. Mat Santamouris (Associate Professor of Energy Physics, University of Athens, Greece);

Prof. Olli Seppänen (Secretary General of REHVA, Fed of European Heat, Vent and AC Assaciatons Belgrum);

Dr. (John) Chia Yu Shaw (Ottawa, Canada):

Dr. Chandra Sekhar (School of Design and Environment, Nattonal University of Singapore, Singapore);

Dr. Jerzy Sowa (Warsaw University of Technology, Institude of Heating and Ventilation, Poland);

Prof. Hir oshi Yoshino (Tohoku University, Dept. of Architecture and Bulding Sciences, Japan):

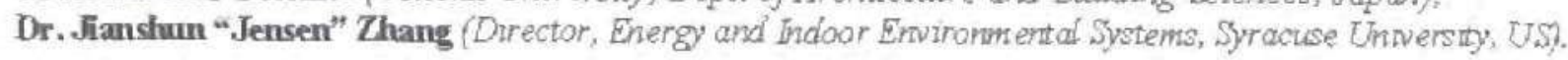

Editor. Dr. Martin W. Liddament (VEETECH Ltd. UK)

6 VEETECH Ltd 2013 (Ventilation Energy and Environmental Technology) No part of this Journal may be uploaded on to the world wide web or any other public access system without the express permission of the publisher

Published by VEETECH Lid

7 A. Barclay's Venture Centre.

The University of Warwick Science Park.

Sir William Lyons Road,

COVENTRY

United Kingdom

CV4 7EZ

Tel $\quad+44(0) 1189477231$

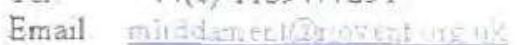

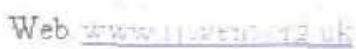

Cover Design Zoe Lawson, Wyats Intermatonal Ltd.

Paper Meets Nordic and European environm ental standards andis sourced from sustanable forests, totally chlonne free.

Binding of printed edition Kew Bookbinding

E-Edition: This Journal is available on tine via Allen Press and major providers

Disclaimer: The views expressed in this Journal need not necessarily reflect those of the Publisher or of the Editorial Board. Information published in the International Joumal of Ventilation is intended for research purposes only and is not validated for legal applications. 


\title{
Correlation of Particulate Matter with Airborne Fungi in Schools in Greece
}

\author{
P.V. Dorizas ${ }^{1}$, E. Kapsanaki-Gotsi ${ }^{2}$, M.N. Assimakopoulos' ${ }^{1}$ and M. Santamouris ${ }^{1}$ \\ ${ }^{1}$ Faculty of Physics, Department of Environmental Physics and Meteorology, University of Athens, \\ University Campus, Building of Physics -5, GR-157 84, Athens, Greece \\ ${ }^{2}$ Faculty of Biology, Department of Ecology and Systematics, University of Athens, \\ Panepistimiopolis, GR-15784, Athens, Greeee
}

\begin{abstract}
The eoncentration levels of particulate matter (PM), airborne fungi, carbon dioxide as well as temperature and relative humidity were investigated in the indoor and outdoor environment of two schools in Athens, Greece during the period January to May 2011. The overall coneentration ranges of the indoor measured pollutants were: $\mathrm{PM}_{10}: 14.92-166.18 \mu \mathrm{g} / \mathrm{m}^{3}, \mathrm{PM}_{25}: 3.16-31.27 \mu \mathrm{g} / \mathrm{m}^{3}, \mathrm{PM}_{1}: 0.72-9.01 \mu \mathrm{g} / \mathrm{m}^{3}$, UFP: 4188 $63093 \mathrm{pt} / \mathrm{cm}^{3}$, total airbome fungi: $28-2098 \mathrm{CFU} / \mathrm{m}^{3}$ and $\mathrm{CO}_{2}: 389-1717 \mathrm{ppm}$. The relationships between PM and airborne fungi were mainly examined, and bivariate correlations of all the measured environmental parameters are also reported. The results indicate that PM of certain aerodynamic diameters significantly correlate to the total airborne fungi and their prevalent genera, Penicilizum, Cladosporion and Aspergillus. Principal Component Analysis (PCA) was conducted so as to eluster variables of common characteristics. Furthermore, simple and multiple linear regression models were developed to investigate several cases of dependent variables to be used for prediction purposes in health risk assessments.
\end{abstract}

Key words: indoor air quality, schools, particulate matter, airbome fungi, PCA, multiple linear regression models.

\section{Introduction}

The study of Indoor Air Quality (IAQ) has attracted the interest of the scientific community in recent years, especially since people spend approximately $85-90 \%$ of their time in indoor environments (EPA 1995a; Jenkins et al, 1992; Long et al, 2001). Epidemiological studies have associated exposure to indoor air pollutants, such as particulate matter (PM) and airborne fungi, to human health effects (Chapman 1999; Pope III et al, 1995). The eftects of PM include headaches, asthma symptoms, allergies, respiratory and cardiovascular diseases and even mortality (Brunekreef and Holgate, 2002; Dockery et al, 1993; Donaldson and Stone, 2003). The small size and relatively large surface are to volume ratio of particles in the ultrafine size range (UFP $<100 \mathrm{~nm}$ in diameter) result in their ability to penetrate deeper into the lungs and alveoli and may have higher reactivity and toxicity compared to larger particles (Oberdörster, 2000). Effects of airborne fungi include irritations, infections, respiratory allergies and asthma (Adhikari et al, 2004; Burge and Rogers, 2000; Bush and Portnoy, 2001;
Pongracic et al, 2010). Children are more vulnerable to health problems compared to adults, due to the greater volume of air inhaled in proportion to their body weight. Owing to their developing lungs, they may be especially susceptible to particle inhalation (EPA, 1995b). Students, in particular, spend a substantial amount of their day time within school premises (Silvers et al, 1994). Internationally, several epidemiological publications report exposure to air pollutants in school environments in association to health impacts (Guo et al, 1999). Human activities and classrooms overcrowded for several hours, poor ventilation and infrequent cleaning constitute some of the most common sources of air pollutants in school environments. In addition, the indoor air is greatly affected by outdoor pollutant concentrations (Fromme et al, 2008). Degraded IAQ in school classrooms impacts on students' performance, attendance and comfort and may also lead to increased energy consumption, leading to massive societal and economic costs (EPA 1995b; Mendell and Heath, 2005; Wargocki and Wyon, 2013). Therefore, the quality of air inside school elassrooms is of primary concern. 
Even though both particulate matter and airborne fungi constitute important indoor air pollutants that cause a great mumber of adverse health effects, there are only a small number of studies in the international literature reporting their simultaneous measurement, interrelationships and interaction (Adhikari et al, 2006; Degobbi et al, 2011; GrinnGofroń et al, 2011; Hargreaves, 2003; Sousa et al, 2008). However, these studies have not been extensively evaluated due to the complex interrelation of the pollutants. In Greece, a quantitative evaluation of bioaerosol in comparison to particulate matter has been made in the ambient air and in residential, office and school buildings (Kalogerakis et al, 2005; Raisi et al, 2010, Dorizas et al, 2012). Nevertheless in school buildings, several studies have been carried out investigating concentration levels of only non-biological air pollutants such as $\mathrm{PM}$, carbon dioxide $\left(\mathrm{CO}_{2}\right)$, carbon monoxide $(\mathrm{CO})$, ozone $\left(\mathrm{O}_{3}\right)$ and Total Volatile Organic Compounds (TVOCs) (Diapouli et al, 2007; Lazaridis and Aleksandropoulou, 2009; Santamouris et al, 2008; Synnefa et al, 2003; Triantafyllou et al, 2008).

In this study, an experimental campaign was conducted in two high schools in Athens, Greece. Particulate matter of several size ranges $\left(\mathrm{PM}_{10}, \mathrm{PM}_{2}\right.$, $\mathrm{PM}_{1}$, UFP), $\mathrm{CO}_{2}$, temperature (T) and relative humidity $(\mathrm{RH})$ were measured in school classrooms and the outdoor emvironment, Air sampling was simultaneously conducted for airborne fungi. The fungi were identified to genus level and the prevalent genera were Penicllium, Gadosponium and Aspergilits. The objectives of this work were to:

(i) report the indoor and outdoor concentration levels of the aforementioned air pollutants;

(ii) characterize the indoor environments of classrooms against proposed limit values by intemational certification bodies;

(iii) examine the correlations between the measured parameters focusing on relationships between $\mathrm{PM}$ and airborne fungi;

(iv) deliver simple and multivariate linear regression models.

\section{Materials and Methods}

\subsection{Sampling Site Description}

Measurements were carried out in two vocational high schools from nearby areas outside the city centre of Athens. The first school is in the
Kaisaniani urban area, hereafter denoted by $\mathrm{K}$. This school is located away from major highways and is next to a park. It was constructed in 2001 and has double glazed windows installed. The second school is in the Ymittos urban area, hereafter denoted by $\mathrm{Y}$, where the traffic in the adjoining streets is moderate. This school was construeted in 1930 and all of the building's windows are single glazed. Central heating systems are used in both of the two schools and are oil-fired boilers that heat water to provide central heating via radiators. Both schools are naturally ventilated.

\subsection{Sampling Strategy}

The sampling period was from January until May 2011 and measurements were conducted onee every two weeks in each school. Air samples were collected from eight sampling sites denoted by $\mathrm{K} 1$ to $\mathrm{K} 8$ and $\mathrm{Y} 1$ to $\mathrm{Y} 8$ for schools $\mathrm{K}$ and $\mathrm{Y}$ respectively. One of the measurement sites was the outdoor environment where the instruments were placed on the schools' roof-yards (positions K8 and Y8). The other seven sampling positions were classrooms and laboratories. Certain elassrooms were occupied by students during sampling throughout the measurement period. The number of students before and during the measurements, the prevailing conditions such as open windows before the measurement or any detected odours was logged. The windows were kept closed while the measurements were earried out. The sampling apparatus were synchronized and were placed each time at the same location of $0.8 \mathrm{~m}$ above the floor.

\subsection{Parameters Measured and Instrumentation}

$\mathrm{PM}_{10}, \mathrm{PM}_{25}, \mathrm{PM}_{1}$ (where 10, 2.5 and 1 refer to the aerodynamic diameter of the particles in $\mu \mathrm{m}$ ) were measured in units of mass per unit volume $\left(\mu \mathrm{g} / \mathrm{m}^{3}\right)$ using Osiris, an airborne particulate monitor (Turnkey Instruments Ltd). UFP concentrations were measured in units of number of particles per unit volume (particles $/ \mathrm{cm}^{3}$ ) using P-Trak, a portable particle counter (TSI, Model 8525). The particle detection range of this instrument is from $20 \mathrm{~nm}$ to about $1 \mu \mathrm{m}$. Carbon dioxide $\left(\mathrm{CO}_{2}\right)$ was recorded using LAQ-CALC, a portable instrument meter from TSI (TSI model 8732). Temperature (T) and relative humidity $(\mathrm{RH})$ were recorded using self-contained sensors ineorporated in Tinytag dataloggers (Gemini data loggers TGP-4500). All these parameters were monitored with a sampling step of 1 second and the duration of each measurement, per position, was 10 minutes. 
Airborne fungi were recovered using a Burkard (Burkard Manufacturing Co. Ltd. Hertfordshire, UK), a portable air sampler for agar plates. Three plates with Malt Agar were exposed consecutively in each sampling site for $3 \mathrm{~min} /$ plate and then incubated for 2 weeks at $28^{\circ} \mathrm{C}$. The colony count was corrected and expressed as colony forming units per cubic meter $\left(\mathrm{CFU} / \mathrm{m}^{3}\right)$, a measure of viable spore concentrations. The fungal colonies were identified to genus level and Penicllirum Cladosportum and Aspergillis were the predominant genera.

\subsection{Statistical Analysis}

Statistical analysis was performed using the SPSS (SPSS Ine PASW Statistics 18) statistical software package as well as data analysis of Microsoft Excel 2007. The concentrations of the pollutants per measurement position and day were studied by temporal variation graphs, and the range of values which the PM concentrations laid are presented in box-plots. Furthermore, Principal Component Analysis (PCA) was performed in order to cluster variables of eommon characteristics. In addition Spearman's correlation coefficients were calculated among all possible pairs of measured variables so as to investigate bivariate relationships. Simple and multiple stepwise linear regression analyses were also performed to examine combined and individual influence between the environmental variables.

\section{Measurements Results}

\subsection{Particulate Matter Concentrations}

The variation in time of $\mathrm{PM}_{10}$ concentrations, in units of $\mu \mathrm{g} / \mathrm{m}^{3}$, in the course of the campaign is presented in Figure 1 (Figure 1, left is for school $\mathrm{K}$ and right is for school Y) (Dorizas et al, 2012). Each diagram contains 8 graphs (one for each sampling position). $\mathrm{K} 8$ and $\mathrm{Y} 8$ graphs refer to the measurements in the outdoor environment. The horizontal line denoted by $\mathrm{LV}$ corresponds to the 24 -h limit value of $\mathrm{PM}_{10}$ (50 $\mu \mathrm{g} / \mathrm{m}^{3}$ ) recommended by the World Health Organization (WHO, 2005). The overall indoor $\mathrm{PM}_{40}$ concentrations in both schools ranged between 14.92 and $166.18 \mu \mathrm{g} / \mathrm{m}^{3}$. In particular, the mean concentration of $\mathrm{PM}_{10}$ indoors was $64.53 \mu \mathrm{g} / \mathrm{m}^{3}$ and ranged between $18.27 .166 .18 \mu \mathrm{g} / \mathrm{m}^{3}$ in school $\mathrm{K}$ (Figure 1 left), and $38.65 \mu \mathrm{g} / \mathrm{m}^{3}$ and 14.92-116.14 $\mu \mathrm{g} / \mathrm{m}^{3}$ in school Y respectively (Figure $1 \mathrm{right}$ ). Higher concentrations appear at school $\mathrm{K}$ exceeding the limit values in many cases (Figure 1 left e.g. K3 graph, st.dev. $=46$ ), whereas in school $\mathrm{Y}$ the concentrations are significantly lower in almost all measurement positions, with a few exceptions (Figure 1 right e.g. Y3 graph, st.dev. $=32$ ). The intense indoor peaks for certain dates are possibly attributed to:

(i) the increased presence of students being in the classrooms before and during the

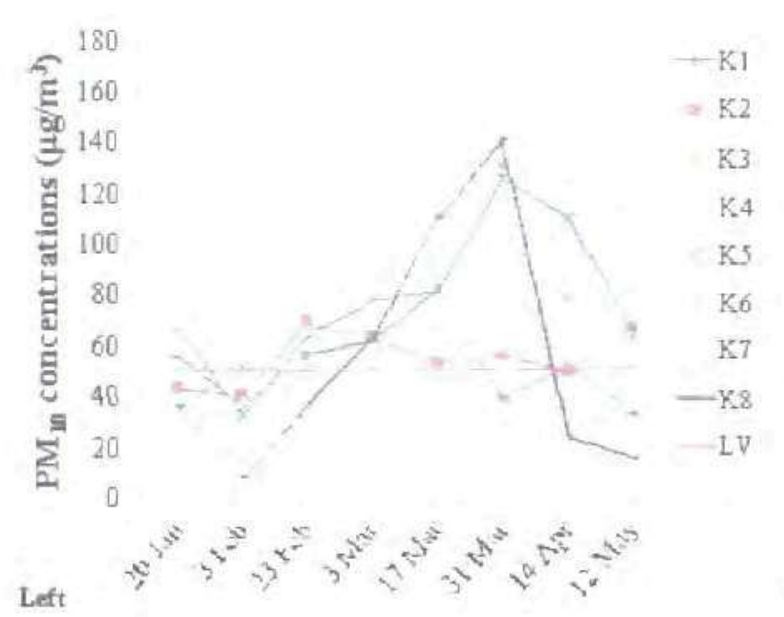

Figure 1. Temporal varzation of $P M_{i D}$ concentrations for all of the measturement sites for schools $K$ (left) and $Y$ (nght). 
measurements; since students' presence and physical movement in the classroom may cause re-suspension of coarse particles and therefore affect their concentrations (Guo et al, 2010);

(ii) inadequate ventilation rates;

(iii) infiltration of particles from construction works that were taking place outside school $\mathrm{K}$ in certain days. It should be noted that in most cases outdoor fresh air did not enter the classrooms so as to meet the ventilation requirements and to remove odours and contaminants.

The averaged $\mathrm{PM}_{10}$ coneentrations at the 7 indoor sites ( $K 1$ to $K 7$ and $Y 1$ to $Y 7$ ) are depieted versus the outdoor concentrations in Figure 2 (Figure 2, left is for school $\mathrm{K}$ and right is for school $\mathrm{Y}$ ). The outdoor concentrations ranged from 7 to $139 \mu \mathrm{g} / \mathrm{m}^{3}$ in school $\mathrm{K}$ and from 12 to $41 \mu \mathrm{g} / \mathrm{m}^{3}$ in school $\mathrm{Y}$. Most indoor measurements were greater than the corresponding outdoor ones for both schools and they seem to follow the same trend, especially at school Y. The majority of the indoor measurements of school K, exceeded the limit value. The exteme outdoor $\mathrm{PM}_{10}$ concentrations on the $17^{\text {th }}$ and $31^{\text {st }}$ of March in school $\mathrm{K}$ are possibly linked to the increased levels of relative humidity, as in both of these days it was drizzling during the measurements. In addition, over these days a strong smell of smoke was detected outside school $\mathrm{K}$, which could have also affected the concentrations. Average indoor and outdoor $\mathrm{PM}_{10}$ concentrations in school $\mathrm{Y}$ were below the recommended limit value, excluding the indoor measurements on the $5^{\text {th }}$ of May.
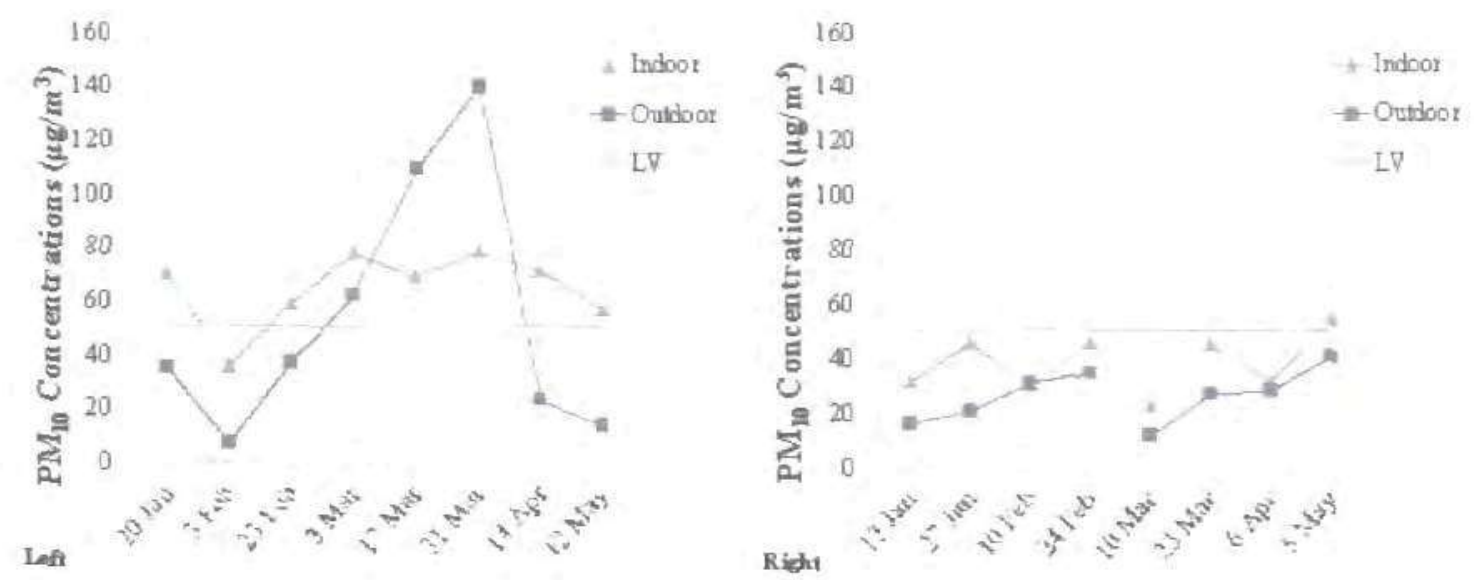

Figure 2. Averaged indoor versus au tioor $P M_{10}$ concentratson fuctuatons for schools $K$ (left) and $Y$ (nght).
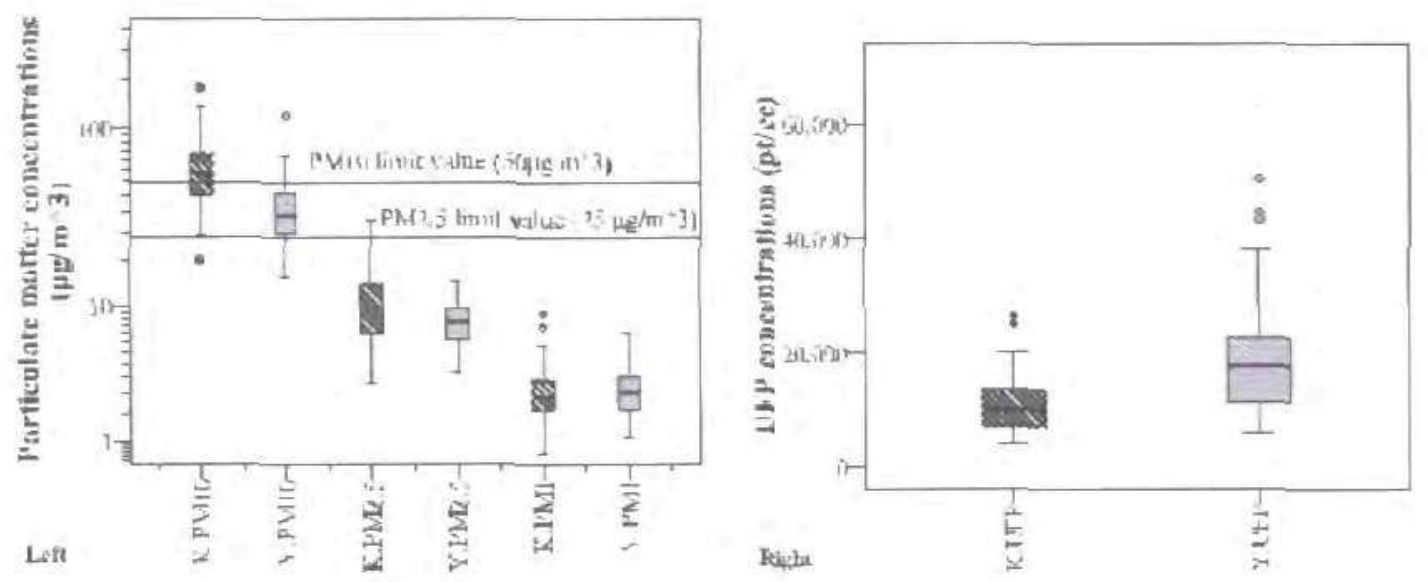

Figure 3. Cancentration distributions of $P M_{10} P M_{25}$, and $P M_{1}$ (left) and of UFP (nght) in schools $K$ (striped) and $Y$ (grey), presented in box plots. 
The indoor concentration distributions of $\mathrm{PM}_{10}$, $\mathrm{PM}_{25}, \mathrm{PM}_{1}$ (Figure 3 , left) and of UFP concentrations (Figure 3, right) for both schools are illustrated as box plots. A percentage of $60 \%$ of the total average $\mathrm{PM}_{10}$ concentrations in school $\mathrm{K}$ and of $17 \%$ in school $\mathrm{Y}$, exceeded the limit value of $50 \mu \mathrm{g} / \mathrm{m}^{3}$. Although school $\mathrm{K}$ is more recently construeted compared to school $\mathrm{Y}$, the inereased $\mathrm{PM}_{10}$ concentrations indoors may have been due to the inereased concentrations outdoors (Figure 2 left). It is possible that $\mathrm{PM}_{10}$ concentrations were influenced by construction works that were carried out on certain days outside school $\mathrm{K}$, where dust clouds were frequently visible. Furthermore, in certain cases, the surface area per pupil in school $\mathrm{K}$ was smaller than in school $\mathrm{Y}$ and the intense movement and activity from the increased presence of students caused resuspension of particles of greater size, increasing their concentrations. $\mathrm{PM}_{2.5}$ concentrations indoors ranged from 3.16 to $31.27 \mu \mathrm{g} / \mathrm{m}^{3}$ in school $\mathrm{K}$ and from 3.75 to $18.05 \mu \mathrm{g} / \mathrm{m}^{3}$ in school $\mathrm{Y}$. The limit value of $25 \mu \mathrm{g} / \mathrm{m}^{3}$ for $\mathrm{PM}_{2}$ s was only exceeded in school $\mathrm{K}$ by $5 \%$ (Figure 3 left). The UFP coneentrations ranged from 4188 to $26518 \mathrm{pt} / \mathrm{cm}^{3}$ in school $\mathrm{K}$ and from 5789 to $63093 \mathrm{pt}^{\mathrm{cm}} \mathrm{cm}^{3}$ in school $\mathrm{Y}$ (Figure 3 right). The UFP concentrations in school $\mathrm{Y}$ were greater than the corresponding ones of school $\mathrm{K}$ and also present a stronger dispersion around the mean value. The increased UFP concentrations in school $Y$ were possibly linked to vehicle emissions from the adjoining streets. Furthemore, due to the single and unsealed glazed windows of the construction of school $\mathrm{Y}$, outdoor air pollutants may infiltrate more easily into the indoor environment

\subsection{Airborne Fungi Concentrations}

The temporal variation of the total airborne fungi concentrations for both schools, expressed in $\mathrm{CFU} / \mathrm{m}^{3}$, is presented in a logarithmic scale in Figure 4 (Dorizas et al, 2012). Each diagram contains 8 graphs (one for each sampling site). K8 and Y8 graphs refer to the outdoor measurements. The overall indoor airborne fungi concentrations in both schools ranged between 28 and $2098 \mathrm{CFU} / \mathrm{m}^{3}$. In particular, the mean concentration of the total airborne fungi concentrations indoors was $191 \mathrm{CFU} / \mathrm{m}^{3}$ and ranged between $28-2098 \mathrm{CFU} / \mathrm{m}^{3}$ excluding 1 extreme peak $\left(5685 \mathrm{CFU} / \mathrm{m}^{3}\right)$ in school $\mathrm{K}$ (Figure 4 left) and $146 \mathrm{CFU} / \mathrm{m}^{3}$ and 28 $866 \mathrm{CFU} / \mathrm{m}^{3}$ in school Y respectively (Figure 4 right). School $\mathrm{K}$ presents higher concentrations of airbome fungi as is the ease for PM. There does not exist a universally acceptable threshold limit value for fungal concentrations.

The averaged total airborne fungi concentrations at the 7 indoor sites ( $\mathrm{K} 1$ to $\mathrm{K} 7$ and $\mathrm{Y} 1$ to $\mathrm{Y} 7$ ) are presented versus the outdoor concentrations in Figure 5. The outdoor concentrations of the total airborne fungi ranged from 51 to $410 \mathrm{CFU} / \mathrm{m}^{3}$ in school $\mathrm{K}$ and from 69 to $236 \mathrm{CFU} / \mathrm{m}^{3}$ in school $\mathrm{Y}$. In most of the measurements, the indoor concentrations follow the trend of the corresponding outdoor ones. In the case of school Y (Figure 5 right), the indoor concentration levels seemed to be mostly affected by the outdoor concentrations, which probably indicates the absence of major indoor sources.
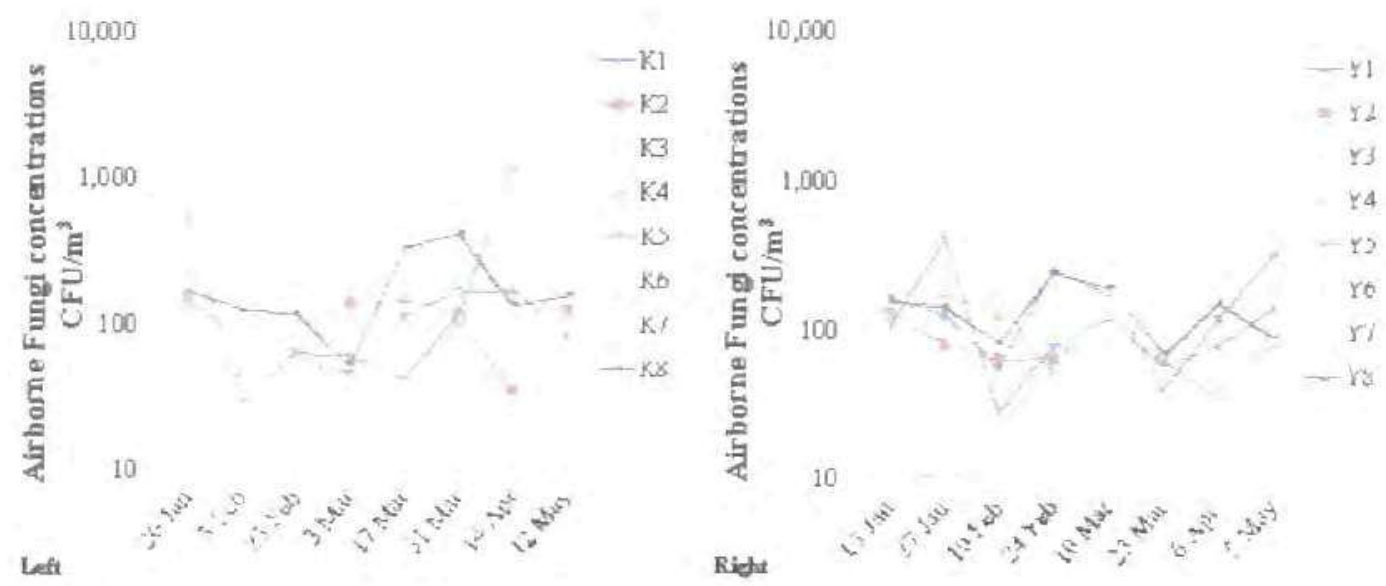

Figure 4. Temporal vanation of ax borne fung concentratons 3 all of the measurement sites, for schools $K$ (left) and $Y$ (right). 

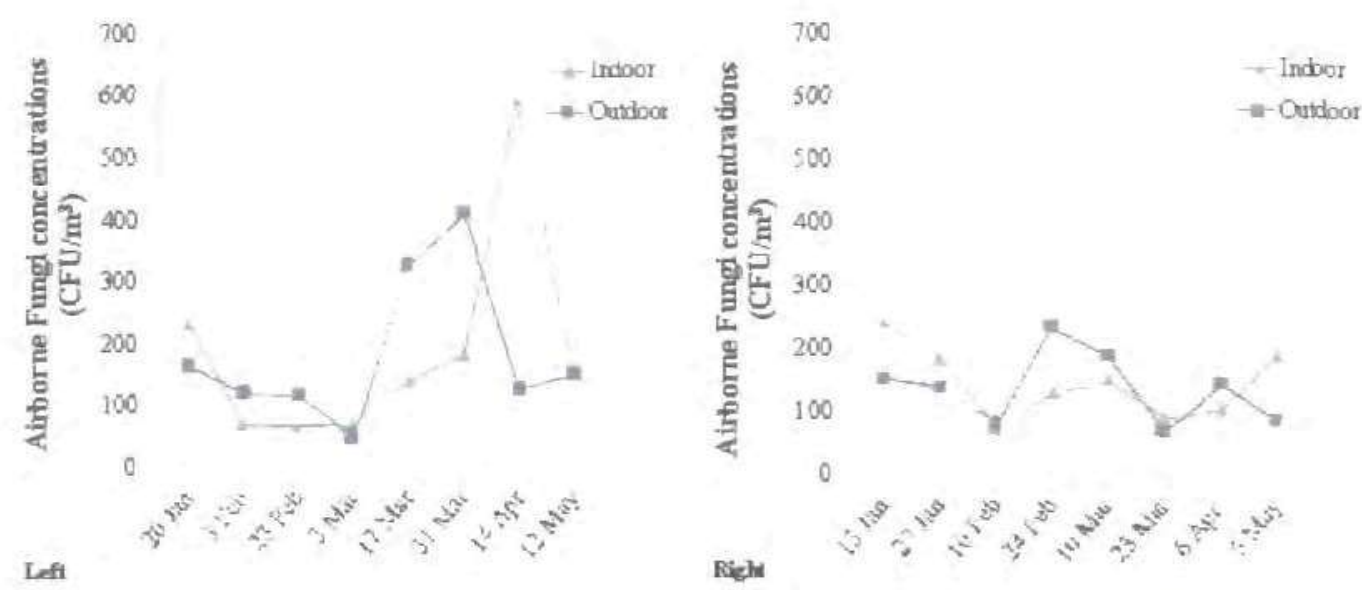

Figure 5. Averaged indoor versus outdoor as rborne fung concentration fuctuations for schools $K$ peft) and $Y$ (right).

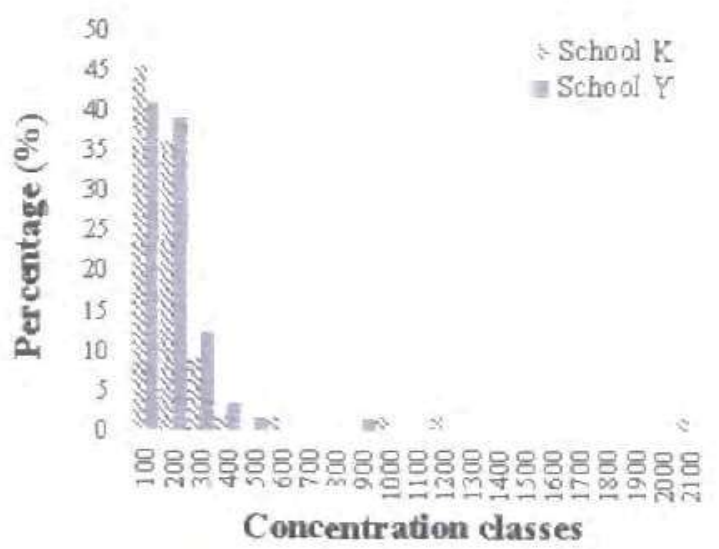

Figure 6. Frequency distribition of the total airborme fungi cancentrations in classes of $100 \mathrm{CF}^{2} \mathrm{~m}^{3}$ in schools $K$ (struped) and $Y$ (grey).

The frequency distribution of the total airborne fungi concentrations in the two schools is indicated in Figure 6, along 21 classes of $100 \mathrm{CFU} / \mathrm{m}^{3}$, ranging from 100 to 2100 . More than $90 \%$ of the total airborne fungi concentrations are between 100 and $300 \mathrm{CFU} / \mathrm{m}^{3}$ for both schools. However, there was a small percentage, especially in school $\mathrm{K}$, which distributed from 400 to $2098 \mathrm{CFU} / \mathrm{m}^{3}$.

The predominant genera found in the indoor environment of the classrooms were Penicillizm, Cladosporium and Aspergillus. Penicilinum concentrations ranged from 0 to $872 \mathrm{CFU} / \mathrm{m}^{3}$ in school K and from 6 to $476 \mathrm{CFU} / \mathrm{m}^{3}$ in school Y. The concentration ranges for Cladosportum, were from 0 to $585 \mathrm{CFU} / \mathrm{m}^{3}$ in school $\mathrm{K}$ and from 0 to
$134 \mathrm{CFU} / \mathrm{m}^{3}$ in school Y. Aspergillus concentrations extended from 0 to 17 and 0 to $176 \mathrm{CFU} / \mathrm{m}^{3}$ in schools $\mathrm{K}$ and $\mathrm{Y}$ respectively.

\section{3 $\mathrm{CO}_{2}$ Concentration}

$\mathrm{CO}_{2}$ concentrations are often used as an indicator of ventilation efticiency and the assessment of indoor air quality and the excess of occupancy (Mumovic et al, 2009, Santamouris et al, 2008). In this case, $\mathrm{CO}_{2}$ concentrations ranged from 389 to $1717 \mathrm{ppm}$ in school K and from 460 to $1377 \mathrm{ppm}$ in school Y throughout the measurement period. On every sampling day the number of students oceupying the elassrooms was marked down. The linear correlation between indoor $\mathrm{CO}_{2}$ concentrations and 


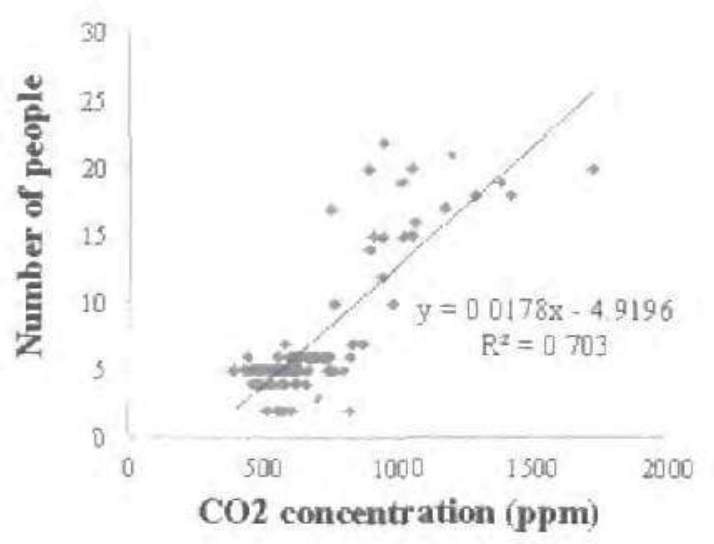

Figure 7. Scatter plot of $\mathrm{CO}_{2}$ concentrations versus number of people.

the number of people being present during sampling for both schools in all indoor sites of measurement is presented in Figure 7. As expected $\mathrm{CO}_{2}$ concentrations are highly correlated to the number of occupants $\left(r^{2}=0.703, N=112\right)$. In many eases $\mathrm{CO}_{2}$ concentrations exceeded the more recent recommended standards of ASHRAE (62.2001 and $62-2004)$ of $700 \mathrm{ppm}$ indicating inadequate ventilation rates and overcrowded classrooms. Insufficient ventilation contributes to the inhibition of the removal of larger particles from the indoor to the outdoor environment (Almeida et al, 2010).

\section{Common Data Set of Measurements of the Two School}

The areas to which the datasets of the measured parameters in the two schools extend, are visualized in a rose diagram in Figure 8 . The maximum values of each variable have been used as input for the design of the diagram. The area where the variables of school $\mathrm{K}$ occur, is presented in black and for school $\mathrm{Y}$ is shown in grey. The common area of the data is where the data trom the two schools overlap, and is presented in dark grey. The common area represents a percentage of approximately $66 \%$ of the total number of measurements from both schools.

Descriptive statistics of all the indoor measured environmental parameters of schools $\mathrm{K}(\mathrm{N}=55), \mathrm{Y}$ $(N=56)$ and of the common area (denoted by $C$, $\mathrm{N}=73$ ) of the dataset are summarized in Table 1. Both mean $\mathrm{PM}_{10}$ and $\mathrm{PM}_{2}$ s concentrations of the common area were below the recommended WHO limit values. The extreme values (outside the common area of Figure 8) were filtered out and hereafter any statistical analysis refers to the data set of the common area of size $\mathrm{N}=73$.

\section{Results and Discussion}

This study primarily investigated correlations between particulate matter and airborne fungi concentrations, as well as further correlations such as $\mathrm{PM}_{\mathrm{J}}$ versus temperature. To this end, a four-step analysis procedure was ap plied as follows:

Step 1. Prineipal Component Analysis (PCA) was applied to the entire set of variables of the common area so as to identify hidden pattem correlations in the data. These were categorized according to the amount of information stored in the data set they represent.

Step 2. Spearman's rank correlation coefficients were calculated amongst all the pairs of variables.

Step 3. Linear regression models were developed from all the statistically significant pairs of values.

Step 4. Several multiple linear regression models were further delivered aiming to be used for prediction purposes. According to the findings from PCA, certain variables were excluded from the regression models in each case. 


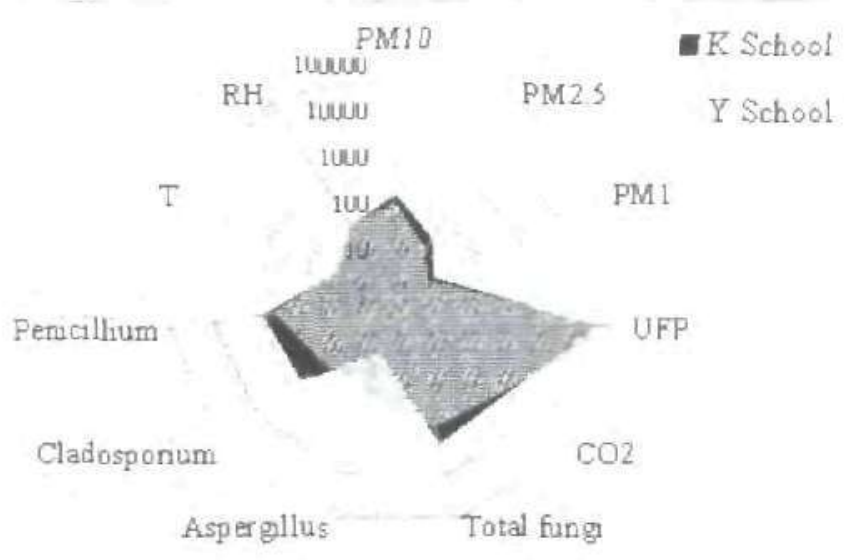

Figure 8. Rose diagram created from the maximum values of each wariable in each of the two schools.

Table 1. Descriptue statistacs of the indoor enrrommental parameters of Schools $K, Y$ and of the common filtered area (denoted by C).

\begin{tabular}{|c|c|c|c|c|c|c|}
\hline Vanables & School & Minimum & Maximum & Mean & Median & $\begin{array}{c}\text { Std } \\
\text { Deviation }\end{array}$ \\
\hline \multirow{3}{*}{$H^{\prime} M_{10}\left(\mu g / m^{3}\right)$} & $K(N=55)$ & 18.27 & 166.18 & 6453 & 5594 & 3207 \\
\hline & $\gamma(N=56)$ & 1492 & 11614 & 38.65 & 3374 & 1935 \\
\hline & $C(N=73)$ & 1492 & 116.14 & 4783 & 4369 & 2066 \\
\hline \multirow{3}{*}{$P M_{25}\left(\mu g / m^{3}\right)$} & $K(N=55)$ & 316 & 3127 & 1090 & 9.76 & 552 \\
\hline & $Y(N=56)$ & 375 & 18.05 & 819 & 781 & 278 \\
\hline & $C(N=73)$ & 316 & 17.58 & 871 & 799 & 297 \\
\hline \multirow{3}{*}{$P M_{1}\left(\mu g i m^{3}\right)$} & $K(\mathrm{~N}=55)$ & 72 & 901 & 283 & 242 & 1.58 \\
\hline & $Y(N=56)$ & 1.09 & 681 & 294 & 275 & 129 \\
\hline & $C(N=73)$ & 0.72 & 681 & 259 & 239 & 108 \\
\hline \multirow{3}{*}{$\operatorname{UFP}\left(\mathrm{pt} / \mathrm{cm}^{3}\right)$} & $K(N=55)$ & 4188 & 26518 & 10853 & 9774 & 4895 \\
\hline & $Y(N=56)$ & 5789 & 63093 & 19333 & 17530 & 11392 \\
\hline & $C(N=73)$ & 4188 & 26518 & 12365 & 10059 & 5865 \\
\hline \multirow{3}{*}{$\mathrm{CO}_{2}(\mathrm{ppm})$} & $K(N=55)$ & 389 & 1717 & 666 & 588 & 265 \\
\hline & $Y(N=56)$ & 460 & 1377 & 674 & 601 & 187 \\
\hline & $C(N=73)$ & 389 & 1377 & 613 & 570 & 166 \\
\hline \multirow{3}{*}{$\begin{array}{l}\text { Total Fung } \\
\left(\mathrm{CFU} / \mathrm{m}^{3}\right)\end{array}$} & $K(N=55)$ & 28 & 2098 & 191 & 104 & 329 \\
\hline & $Y(N=56)$ & $2 \theta$ & 866 & 146 & 123 & 128 \\
\hline & $C(N=73)$ & 28 & 310 & 102 & 80 & 67 \\
\hline \multirow{3}{*}{$\begin{array}{l}\text { A spergilus } \\
\text { (CFU/m }\end{array}$} & $K(N=55)$ & 0 & 17 & 3 & 0 & 4 \\
\hline & $Y\langle N=56\}$ & 0 & 176 & 15 & 6 & 34 \\
\hline & $C(N=73)$ & 0 & 17 & 3 & 0 & 4 \\
\hline \multirow{3}{*}{$\begin{array}{l}\text { Cladosponum } \\
\left(\mathrm{CFU} / \mathrm{m}^{3}\right)\end{array}$} & $K(N=55)$ & 0 & 585 & 43 & 23 & 85 \\
\hline & $Y(N=56)$ & 0 & 134 & 22 & 17 & 24 \\
\hline & $C(N=73)$ & 0 & 116 & 22 & 17 & 21 \\
\hline \multirow{3}{*}{$\begin{array}{l}\text { Penicillum } \\
\left.\text { (CFU/m }{ }^{3}\right)\end{array}$} & $K(N=55)$ & 0 & 872 & 99 & 40 & 177 \\
\hline & $Y(N=56)$ & 6 & 476 & 76 & 86 & 75 \\
\hline & $C(\mathrm{~N}=73)$ & 0 & 227 & 51 & 34 & 45 \\
\hline \multirow{2}{*}{$T\left({ }^{\circ} \mathrm{C}\right)$} & $K(N=55)$ & 1583 & 2219 & 1967 & 20.18 & 151 \\
\hline & $Y(N=56)$ & 11.95 & 23.23 & 1884 & 1868 & 221 \\
\hline \multirow{4}{*}{$\mathrm{RH}(\%)$} & $C(N=73)$ & 1483 & 22.19 & 1937 & 1982 & 18 \\
\hline & $K(N=55)$ & 47.14 & 6690 & 5388 & 5320 & 467 \\
\hline & $Y(N=56)$ & 2631 & 75.48 & 5087 & 52.17 & 1265 \\
\hline & $C(N=73)$ & 26.31 & 65.14 & 5144 & 5242 & 753 \\
\hline
\end{tabular}




\subsection{Principal Component Analysis}

Principal Component Analysis (PCA) is a method of reducing the dimensionality of the dataset while keeping the information and variability of the data. It is a mathematical procedure which transforms a set of possibly related variables into a set on uncorrelated variables. The new vaniables are called principal components (PCs) and are linear correlations of the initial set of variables. The first $\mathrm{PC}$ has the largest possible variability and each next PC has the largest proportion of the variability that has not been explained by the first component (Gaitani et al, 2010; Jolliffe 2002). PCA also gives a hint conceming the correlations between parameters.

PCA was applied on the eleven parameters of the data set of the common area $(\mathrm{N}=73)$. These parameters were $\mathrm{PM}_{10}, \mathrm{PM}_{25}, \mathrm{PM}_{1}$, UFP, $\mathrm{CO}_{2}$, Total Fungi, Pencillium, Cladosponum, Aspergilins, temperature and relative humidity. In order to identify the number of significant PCs, the Varimax Rotation method was applied. Four components which had eigenvalues greater than one were examined (Table 2). The four component solution accumulates $71.848 \%$ of the total variance.

Table 2. Rotated component matrix.

\begin{tabular}{|c|c|c|c|c|}
\hline & \multicolumn{4}{|c|}{ Component } \\
\hline & 1 & 2 & 3 & 4 \\
\hline$P M_{10}$ & 162 & .755 & 169 & 138 \\
\hline $\mathrm{PM}_{25}$ & .066 & .586 & 086 & .737 \\
\hline$P M_{1}$ & -.041 & -082 & .059 & .952 \\
\hline UFP & 276 & -104 & .848 & 100 \\
\hline $\mathrm{CO}_{2}$ & -124 & 194 & .793 & 018 \\
\hline Total fung & .960 & 139 & 094 & .043 \\
\hline Aspergilius & 098 & $4 \subseteq 3$ & 202 & -066 \\
\hline Cladosporum & .828 & 183 & -183 & 000 \\
\hline Penvallum & .876 & -044 & 238 & .026 \\
\hline$T$ & 025 & .808 & -151 & .022 \\
\hline $\mathrm{RH}$ & -041 & .506 & -302 & 302 \\
\hline Eigenvalue & 2950 & 2195 & 1595 & 1164 \\
\hline$\%$ of variance & 26816 & 19952 & 14500 & 10581 \\
\hline Cumulative $\%$ & 26816 & 46.768 & 61258 & 71.848 \\
\hline
\end{tabular}

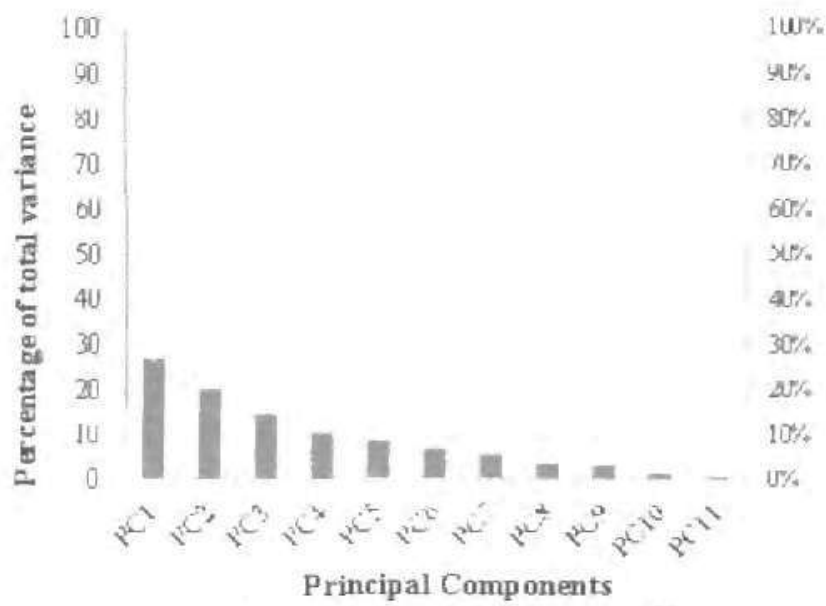

Figure 9. Percentage of the total variance of all the pruncipal components. 
The first component accounts for $26.816 \%$ of the total variance and presents strong positive contribution from total fungi, Penicilisum and Cladosportam. This component represents the biological agent.

The second component is associated with loadings of coarse particulate matter $\left(\mathrm{PM}_{10}\right.$ and
$\mathrm{PM}_{25}$ ) and environmental parameters ( $\mathrm{T}$ and $\mathrm{RH}$ ) explaining $19.952 \%$ of the total variance.

The third component representing $14.5 \%$ of the variance is highly correlated with UFP and $\mathrm{CO}_{2}$

Finally the fourth component, which explains $10.581 \%$ of the variance, is associated with high

Table 3. Correlaaon matrix of Spearman's rank correlation coeffictents between the measured enviromental variables $(N=73)$.

\begin{tabular}{|c|c|c|c|c|c|c|c|c|c|c|c|}
\hline Vanables & $\sum_{i}^{g}$ & $\sum_{0}^{2}$ & $\sum_{a}^{\Sigma}$ & 品 & 8 & 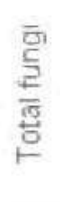 & $\frac{\stackrel{6}{2}}{\frac{6}{0}}$ & $\begin{array}{l}5 \\
\frac{5}{8} \\
\frac{6}{0} \\
\frac{8}{0} \\
0\end{array}$ & $\frac{5}{\frac{1}{2}}$ & $\vdash$ & $\frac{I}{\mathbb{I}}$ \\
\hline$P M_{10}$ & - & 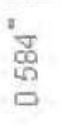 & $\frac{2}{5}$ & $\begin{array}{l}\mathscr{S} \\
\stackrel{5}{\circ}\end{array}$ & $\frac{\sqrt{n}}{0}$ & 导 & " & 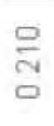 & $\frac{\text { 몸 }}{0}$ & 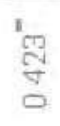 & $\stackrel{\square}{0}$ \\
\hline$P M_{2.5}$ & & - & 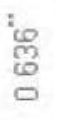 & 賗 & $\frac{\text { gू }}{\frac{0}{0}}$ & $\begin{array}{l}\text { 罗 } \\
\text { 口 }\end{array}$ & $\frac{\infty}{m}$ & $\frac{\text { 哥 }}{\square}$ & $\begin{array}{l}\text { g } \\
\text { O } \\
\text { ? }\end{array}$ & $\begin{array}{l}\text { : } \\
\text { 号 } \\
\text { ป }\end{array}$ & $\frac{5}{\square}$ \\
\hline$P M_{1}$ & & & - & 욤 & $\frac{\infty}{0}$ & $\frac{\square}{g}$ & $\frac{\Xi}{\square}$ & 芩 & $\frac{0}{0}$ & $\stackrel{\mathrm{g}}{0}$ & 밈 \\
\hline UFP & & & & - & $\begin{array}{l}\infty \\
0 \\
0 \\
0 \\
0 \\
0\end{array}$ & $\frac{1}{0}$ & $\begin{array}{l}\infty \\
\stackrel{9}{8} \\
\square\end{array}$ & $\stackrel{\mathscr{g}}{0}$ & $\underset{0}{\infty}$ & $\frac{\infty}{9}$ & $\begin{array}{l}n \\
\frac{1}{0} \\
0\end{array}$ \\
\hline $\mathrm{CO}_{2}$ & & & & & - &  & 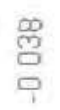 & $\frac{\overline{2}}{9}$ & $\frac{\sigma}{a}$ & $\frac{\Xi}{9}$ & $\begin{array}{l}\mathscr{0} \\
0 \\
0\end{array}$ \\
\hline Total fungr & & & & & & - & $\frac{\Xi}{0}$ & 施 & '8 & $\stackrel{\infty}{=}$ & $\begin{array}{l}\stackrel{\mathscr{C}}{\mathscr{\varrho}} \\
\square\end{array}$ \\
\hline Aspergmus & & & & & & & - & $\frac{\mathscr{D}}{0}$ & $\frac{\infty}{\frac{0}{0}}$ & $\stackrel{\sqrt[\pi]{0}}{\sigma}$ & $\frac{\pi}{0}$ \\
\hline Cladosponurr. & & & & & & & & - & 离 & $\frac{\infty}{0}$ & $\frac{6}{0}$ \\
\hline Pencilhumr. & & & & & & & & & - & $\begin{array}{l}10 \\
5 \\
0 \\
0\end{array}$ & 吕 \\
\hline$T$ & & & & & & & & & & - & 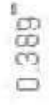 \\
\hline $\mathrm{RH}$ & & & & & & & & & & & - \\
\hline
\end{tabular}


loadings of fine particulate matter $\left(\mathrm{PM}_{25}\right.$ and $\mathrm{PM}_{1}$ ). This component represents the agent of fine particulate matter (Table 2).

The percentage of the total variance of all the principal components (11 PCs) ereated is presented in Figure 9. The curved line corresponds to the cumulative proportion of the total variance when selecting a certain number of components to be kept.

\subsection{Spearman's Rank Correlation Coefficients}

Bivariate correlations of pair wise associations between the variables were calculated. In particular, Table 3 presents a correlation matrix of Spearman's rank correlation coefficients. Statistically significant positive correlations at the 0.01 level were found for the following cases.

1. $\mathrm{PM}_{10}$ versus $\mathrm{PM}_{25}$, Aspergillis, temperature and relative humi dity.

Statistically significant positive correlations between both $\mathrm{PM}_{2 s}$ and $\mathrm{PM}_{10}$ with temperature and Aspergilius, at the 0.01 level of significance, are consistent with the findings of Adhikari et al, (2006). Additionally, Srimuruganandam and Nagendra (2011) and Raisi et al (2010) found associations between $\mathrm{PM}_{10}$ with $\mathrm{PM}_{25}$ $\left(\mathrm{R}_{\text {fearson }}{ }^{2}=0.54-0.76\right.$ and $\mathrm{R}^{2}=0.77$ respectively) similar to results obtained in this work. $\mathrm{PM}_{10}$ and $\mathrm{PM}_{25}$ are also correlated with relative humidity, a fact that confirms the exteme outdoor $\mathrm{PM}_{10}$ concentrations on the $17^{\text {th }}$ and the $31^{\text {st }}$ of March in school K of Figure 2 (left) in which rainfall was observed.

2. $\mathrm{PM}_{25}$ versus $\mathrm{PM}_{1}$, Aspergillus, temperature and relative humidity

Deggobi et al (2011) also report significant positive correlation between $\mathrm{PM}_{25}$ and Aspergilius $\left(R^{2}=0.186, \quad p<0.05\right)$. Srimuruganandam and Nagendra (2011) found stronger correlations between $\mathrm{PM}_{2,5}$ and $\mathrm{PM}_{1}\left(\mathrm{R}_{\text {Peassor }}=0.92-0.98\right)$.

\section{UFP versus $\mathrm{CO}_{2}$ and Pencillinm}

UFP were found to be positively correlated with Pencilizum at the 0.01 level. According to Hargreaves et al (2003) the similarities between airborne fungi and supermicrometre particles can be attributed to the fact that they are both measured in units of number. Particle concentrations are expressed in units of number per unit volume (pt/ec) and airbome fungi are expressed in number of colony forming units (CFU). UFP also correlated to
$\mathrm{CO}_{2}$. This certain relationship was also examined by Weichenthal (2008), however the correlation they found was not significant $\left(R^{2}=0.04\right)$.

\section{Total fungi versus Ciadosportum and Penicilliom}

\section{Aspergilitus versus temperature}

Adhikari et al. (2006) and also Hammed et al. (2012) report statistically significant correlations between. Aspergilitis and temperature.

\section{Cladospontam versus Pencilizum}

Correspondingly, according to Table 3 statistically significant positive correlations at the 0.05 level were found for the following cases:

1. $\mathrm{PM}_{10}$ versus Total fungi.

Contrary to the findings of $\mathrm{Lin}$ and $\mathrm{Li}(2000)$ in which PM $\mathrm{M}_{10}$ correlated with Pennclllum, in this case $\mathrm{PM}_{10}$ significantly correlated with the total airborne fungi at the 0.05 level.

\section{UFP versus total fungi}

Relative humidity for the period of measurement did not have any linear correlation neither to the total airborne fungi nor the prevalent genera, a fact which is in agreement to the findings of Sousa et al, (2008).

Several of the above mentioned correlations are also confirmed with the findings of PCA.

\subsection{Linear Regression Models}

Linear regression models that were developed from the statistically signiticant pairs of variables of Table 3 at the 0.01 level of significance are presented in Table 4. Dependent and independent variables, $\beta$ and $\alpha$ values (of linear regression equation: $\mathrm{y}=\not \mathrm{x}+a), \mathrm{r}^{2}$ values, $\mathrm{r}_{\mathrm{adj}}{ }^{2}$ (adjusted) values and $F$ values of the linear models are shown in Table 4 . The $r^{2}$ values ranged from 0.044 to 0.748 and p-values were all below 0.05 , rejecting the null hypothesis $\mathrm{H}_{0}$ which supports no actual correlation between the variables.

\subsection{Multivariate Linear Regression Models}

Multivariate linear regression models were further developed to investigate several cases of dependent variables. Backward stepwise multiple regression analysis was used so as to examine the predietive strength of each variable (Table 5). 
Table 4. Linear regresston models of the statistically significant pars of mea sured envronmental vanables at the 0.01 level of significance $(N=73$ ).

\begin{tabular}{|c|c|c|c|c|c|c|c|c|}
\hline $\begin{array}{l}\text { Uependent } \\
\text { variable }\end{array}$ & $\begin{array}{l}\text { Independent } \\
\text { vanable }\end{array}$ & $\beta$ & a & $N$ & $r^{2}$ & $\mathrm{rad}^{2}$ & $F$ & $p$ \\
\hline$F M_{10}$ & $\mathrm{PM}_{25}$ & 4.311 & 1030 & 73 & 0.385 & 0376 & 44398 & 0000 \\
\hline$P M_{10}$ & Asoergitus & 1261 & 4462 & 73 & 0.057 & 0.044 & 4303 & 0.042 \\
\hline $\mathrm{PM}_{10}$ & T & 4783 & -44.81 & 73 & 0.174 & 0162 & 14941 & 0000 \\
\hline$P M_{10}$ & $\mathrm{RH}$ & 0668 & 13.42 & 73 & 0.059 & 0.046 & 4488 & 0038 \\
\hline $\mathrm{PM}_{25}$ & $P M_{1}$ & 1669 & 439 & 73 & 0.371 & 0362 & 41829 & 0.000 \\
\hline$P M_{25}$ & Aspergilus & 0190 & 822 & 73 & 0.062 & 0049 & 4.725 & 0033 \\
\hline$P M_{2,5}$ & T & 0694 & -474 & 73 & 0.177 & 0165 & 15.245 & 0.000 \\
\hline $\mathrm{PM}_{25}$ & $\mathrm{RH}$ & 0143 & 1.33 & 73 & 0.132 & 0120 & 10798 & 0.002 \\
\hline UFP & $\mathrm{CO}_{2}$ & 16748 & 209599 & 73 & 0.225 & 0214 & 20612 & 0.000 \\
\hline UFP & Penicilium & 50917 & 976154 & 73 & 0151 & 0139 & 12.647 & 0.001 \\
\hline Total Fungr & Cladosponum & 2371 & 5057 & 73 & 0581 & 0575 & 98467 & 0.000 \\
\hline Total Fungi & Pencilfium & 1.289 & 3589 & 73 & 0751 & 0748 & 214545 & 0.000 \\
\hline Aspergitius & T & 0560 & -8.29 & 73 & 0066 & 0053 & 5041 & 0028 \\
\hline Cladosporium & Pencilium & 0.240 & 9.33 & 73 & 0252 & 0.242 & 23.967 & 0000 \\
\hline
\end{tabular}

Table 5. Stepwise miltianate linear regression models of several combuatrons of the measured envionmental vanables.

\begin{tabular}{|c|c|c|c|c|c|}
\hline Multivanate regression models & N & $r^{2}$ & $r_{3 d i}^{2}$ & F & p \\
\hline \multicolumn{6}{|l|}{1 UFP $=22840979+360.269 \times \mathrm{PM}_{25}+16.584 \times \mathrm{CO}_{2}$} \\
\hline $\begin{aligned}-821626 \times T & -217655 \times \mathrm{RH}+25644 \times \text { Total fung I } \\
& +282739 \times \text { A spergilius }\end{aligned}$ & 73 & 0.476 & 0429 & 10009 & 0.000 \\
\hline $2 \mathrm{PM}_{10}=-51.87+4895 \times T+0095 \times$ Peniciliur: & 73 & 0216 & 0.194 & 9669 & 0000 \\
\hline $\begin{array}{c}\text { 3. } P M_{25}=-10516+000012 \times \text { UFP }+0.592 \times T+0.121 \times \\
R H\end{array}$ & 73 & 0.289 & 0.259 & 937 & 0000 \\
\hline 4. Total fungi $=57.9+0868 \times \mathrm{PM}_{10}+0.004 \times$ UFP & 73 & 0181 & 0.146 & 5.089 & 0,003 \\
\hline 5. Aspergilus $=-11.784+000016 \times$ UFP $+0.639 \times T$ & 73 & 0.121 & 0095 & 48 & 0011 \\
\hline
\end{tabular}

Aceording to the findings of PCA certain independent variables were excluded from certain models which were straightforwardly related to the dependent vanable (see Table 2). For instance, $\mathrm{PM}_{25}$ and $\mathrm{PM}_{1}$ were excluded from the $2^{\text {nd }}$ model in which $\mathrm{PM}_{10}$ was the dependent variable, and Pencillium, Cladosporzum and Aspergillus ware excluded from the $4^{\text {th }}$ model that had the total airbome fungi as dependent variable (Table 5). The presence of these variables would account for most of the variance in the model, restrieting by far the variability of the other parameters.

The p-values of every model were found to be less than 0.05 , indicating that the variation of the models is not due to chance, and the models are useful. The $r^{2}$ values ranged between 0.121 and 0.476 (Table 5 ). Temperature was present in most of the linear 
regression models. A rather moderate correlation stands for the prediction of UFP concentrations given $\mathrm{PM}_{2}, \mathrm{CO}_{2}$, temperature, relative humidity, total airborne fungi and Aspergullus. It is anticipated that this model can be used in the future for prediction purposes (Table 5, model 1).

\section{Conclusions}

The findings from an experimental campaign conducted in two schools in Athens measuring air pollutants were evaluated in this paper. The indoor concentrations of PM and airborne fungi were in many cases similar to the corresponding outdoor values indicating that, in the absence of major indoor sources, the indoor concentrations are greaty affected by the outdoor concentrations. However, in certain cases the indoor concentrations outreached the outdoor ones, possibly due to inadequate levels of ventilation and to overcrowded classrooms. The overall concentration range of the pollutants indicates a rather good indoor air quality with the exception of overload in certain sites. Increased levels of UFP may be linked to vehicle emissions from adjoining streets.

In order to analyse these findings, the total measured environmental parameters were presented in a rose diagram where the common area of the data represented approximately $66 \%$ of the total measurements. Statistical analyses were performed on the filtered from extremes common area of data. PCA was conducted in order to cluster variables of common characteristics. It was found that almost $72 \%$ of the total variance was explained by four principal components. Findings of PCA were further used for the removal of eertain parameters from certain multivariate regression models. Spearman's rank correlation coefficients were also calculated for all pairs of the measured data. Significant positive correlations were found between $\mathrm{PM}_{10}$ and total fungi as well as $\mathrm{PM}_{10}$ and $\mathrm{PM}_{25}$ with Aspergulfus. UFP positively correlated to total fungi and Penicilitum. From the statistically significant bivariate correlations, linear regression models were created where p-values for all relationships were below 0.05 . Multivariate regression models with different cases of dependent variables were also developed using stepwise regression analysis. Weak correlations do exist between particulate matter and airbome fungi coneentrations. Moderate correlation stands for the prediction of UFP given $\mathrm{PM}_{2.5}, \mathrm{CO}_{2}$, meteorologieal parameters and airborne fungi. It is anticipated that these multivariate regression models can be used in the future for prediction purposes. Further measurements are necessary as well as further evaluation of the developed models, in order to improve the understanding of the emvironmental health risks.

\section{Acknowledgments}

This research has been co-financed by the European Union (European Social Fund - ESF) and Greek national funds through the Operational Program "Education and Lifelong Learning" of the National Strategic Reference Framework (NSRF) - Research Funding Program: Heracleitus II. Investing in knowledge society through the European Social Funding.

\section{References}

Adhikari A, Sen MM, Gupta-Bhattacharya S and Chanda S: (2004) "Airborne viable, non-viable, and allergenic fungi in a rural agricultural area of India: A 2-year study at five outdoor sampling stations", Science of the Total Environment, 326, (1-3), pp123-141.

Adhikari A, Reponen T, Grinshpun SA, Martuzevicius D and LeMasters G: (2006) "Correlation of ambient inhalable bioaerosols with particulate matter and ozone: A two-year study". Enviranmental Politution, 140, (1), pp16-28.

Almeida SM, Canha N, Silva A, Freitas MdC, Pegas P, Alves C, Evtyugina M and Pio CA: (2001) "Children exposure to atmospheric particles in indoor of Lisbon primary schools", Atmosphene Envuronment, 45, (40), pp 7594.7599.

Brunekreet B and Holgate ST: (2002) "Air pollution and health", The Lancet, 360, (9341), pp1233-1242.

Chapman JA: (1999) "Update on airborne mold and mold allergy", Aliergy and Asthma Proceedngs, 20 , (5), pp $289-292$.

Burge HA and Rogers CA: (2000) "Outdoor allergens", Envirommental Health Perspectives, 108, (Suppl. 4), pp653-659.

Bush RK and Portnoy JM: (2001) "The role and abatement of fungal allergens in allergic diseases", Joumal of Allergy and Cinncal Immunology, 109. ppS430-S440. 
Degobbi C, Lopes FDTQS, Carvalho-Oliveira R, Muñoz JE and Sal diva PHN: (2011) "Correlation of fungi and endotoxin with PM2.5 and meteorological parameters in atmosphere of Sao Paulo, Brazil", Atmospheric Enviromment, 45, (13), pp2277-2283.

Diapouli E, Chaloulakou A and Spyrellis N: (2007) "Indoor and Outdoor Particulate Matter Concentrations at Schools in the Athens Area", Indoor and Buit Enviromment, 16, (1), pp55-61.

Dockery DW, Pope lii CA, Xu X, Spengler JD, Ware JH, Fay ME, Fay ME, Ferris BG and Speizer FE: (1993) "An association between air pollution and mortality in six U.S. cities", New England Joumal of Medicine, 329, (24), pp1753-1759.

Donaldson K, and Stone V: (2003) "Current hypotheses on the mechanisms of toxicity of ultrafine particles", Annalz dell Istituto Seqperiore di Sanita, 39, (3), pp405-410.

Dorizas PV, Kapsanaki-Gotsi E, Assimakopoulos MN and Santamouris M: (2012) "Particulate matter and airborne fungi concentrations in schools in Athens", Advances in Meteorology, Cimatology and Atmosphersc Physics (Helmis CG and Nastos PT eds.), Springer-Verlag, Berlin Heidelberg, Springer Atmospheric Sciences, 2, pp931-937.

EPA United States Environmental Protection Ageney: (1995a) "The Inside Story: A Guide to Indoor Air Quality". Publications and Resources. http://www.epa.goviaq/pubs/insidestory.html. Accessed 13 March 2012.

EPA United States Environmental Protection Agency: (1995b) "Indoor Air Quality tools for schools", Indoor Air.

http://www.epa.gov/iaq/schools/actionkit.html.

Accessed 13 March 2012.

Fromme H, Diemer J, Dietrich S, Cyrys S, Heinrich J, Lang W, Kiranoglu M and Twardella D: (2008) "Chemical and morphological properties of particulate matter (PM10, PM2.5) in school classrooms and outdoor air", Atmospheric Enviromment, 42, (27), pp6597-6605.

Gaitani N, Lehmann C, Santamouris $M$, Mihalakakou G and Patargias P: (2010) "Using principal component and cluster analysis in the heating evaluation of the school building sector", Applied Enengy, 87, (6), pp2079-2086.
Grinn-Gofron A, Strzelczak A and Wolski T: (2011) "The relationships between air pollutants, meteorological parameters and concentration of airborne fungal spores", Environmental Polltation, 159, (2), pp602-608.

Guo YL, Lin YC, Sung FC, Huang SL, Ko YC, Lai JS, Su HJ, Shaw CK, Lin RS and Dockery DW: (1999) "Climate, traffic-related air pollutants, and asthma prevalence in middle-school children in Taiwan", Environmental Healih Perspectives, 107, (12), pp1001-1006.

Guo H, Morawska L, He C, Zhang YL, Ayoko G and Cao M: (2010) "Characterization of particle number concentrations and PM2.5 in a school: influence of outdoor air pollution on indoor air", Environmental socence and pollution research international, 17, (6), pp1268-1278.

Hammed Abdel AA, Khoder MI, Ibrahim YH, Saeed Y, Osman ME and Ghanem S: (2012) "Study on some factors affecting survivability of airborne fungi". Science of the total ervironment, 414, pp696-700.

Hargreaves M, Parappukkaran S, Morawska L, Hitchins $\mathrm{J}, \mathrm{He} \mathrm{C}$ and Gilbert D: (2003) "A pilot investigation into associations between indoor airborne fungal and non-biological particle concentrations in residential houses in Brisbane, Australia", Science of the total environment, 312, (1-3), pp89-101.

Jenkins PL, Philhips TJ, Mulberg EJ and Hui SP: (1992) "Activity patterns of Califormians: Use of and proximity to indoor pollutant sources", Atmaspherzc Environsent - Part A General Topics, 26 A, (12), pp2141-2148.

Jollifte IT: (2002) "Principal Component AnalysisSecond Edition", Springer Series in Statzstics, Springer-Verlag New York Berlin Heidelberg.

Kalogerakis N, Paschali D, Lekaditis V, Pantidou A, Eleftheriadis $\mathrm{K}$ and Lazaridis M: (2005) "Indoor air quality - bioaerosol measurements in domestic and office premises", Joumal of Aerosol Science, 36, (5. 6), pp751-761.

Lazaridis M and Aleksandropoulou V: (2009) "Sourees and variability of indoor and outdoor gaseous aerosol precursors $\left(\mathrm{O} 3, \mathrm{NOx}\right.$ and VOCs) ${ }^{n}$, Water, Air and Soil Follution: Focus 9, (1-2), pp313. 
Lin WH and Li CS: (2000) "Associations of fungal aerosols, air pollutants, and meteorological factors", Aerosol Sclence and technology, 32, (4), pp359-368.

Long CM, Suh HH, Catalano PJ and Koutrakis P: (2001) "Using time- and size-resolved particulate data to ouantify indoor penetration and deposition bchavior", Envirommental Science and Technology, 35, (10), pp2089-2099.

Mendell MJ and Heath GA: (2005) "Do indoor pollutants and termal conditions in schools influence student performance? A critical review of the literature", Indoor Asr, 15, (1), pp27-52.

Mumovic D, Palmer J, Davies M, Orme M, Ridley I, Oreszezyn T, Judd C, Critehlow R, Medina HA, Pilmoor G, Pearson C and Way P: (2009) "Winter indoor air quality, thermal comfort and acoustic performance of newly built secondary schools in England", Burding and Envrromment, 44, (7), pp1466-1477.

Oberdörster G: (2000) "Toxicology of ultrafine particles: In vivo studies", Philosophical Transactions of the Royal Society A: Mathematical, Physical and Engineering Sciences, 358, (1775), pp2719-2740.

Pongracic JA, O'Connor GT, Muilenberg MI, Vaughn B, Gold DR, Kattan M, Morgan WJ, Gruchalla RS, Smartt E and Mitchell HE: (2010) "Differential effects of outdoor versus indoor fungal spores on asthma morbidity in inner-city children", Joumal of Allergy and Clunical Immunology, 125, (3), pp593-599.

Pope Iii CA, Bates DV and Raizenne ME: (1995) "Health effects of particulate air pollution: Time for reassessment? ", Envromental Heaith Perspectrves, 103, (5), pp472-480.

Raisi L, Lazaridis M and Katsivela E: (2010) "Relationship between airborne microbial and particulate matter concentrations in the ambient air at a Mediterranean site", Glabal Nest Joumal, 12, (1), pp84-91.

Santamouris M, Synnefa A, Assimakopoulos M, Livada I, Pavlou K, Papaglastra M, Gaitani N, Kolokotsa D and Assimakopoulos V: (2008) "Experimental investigation of the air flow and indoor carbon dioxide concentration in classrooms with intermittent natural ventilation", Energy and Buildings, 40, (10), pp1833-1843.
Silvers A, Forence BT, Rourke DL and Loromor RJ: (1994) "How Children Spend Their Time A Sample Survey for Use in Exposure and Risk Assessments", Risk Analysis, 14, (6), pp931-944.

Sousa SIV, Martins FG, Pereira MC, Alvim-Ferraz MCM, Ribeiro H, Oliveira M and Abreu I: (2008) "Influence of atmospheric ozone, PM10 and meteorological factors on the concentration of airborne pollen and fungal spores". Ammospheric Environment, 42, (32), pp7452-7464.

Srimuruganandam B and Shiva Nagendra SM: (2011) "Characteristics of particulate matter and heterogeneous traffic in the urban area of India", Atm ospheric Environment, 45, (18), pp3091-3102.

Synnefa A, Polichronaki E, Papagiannopoulou E, Santamouris M. Mihalakakou G, Doukas P, Siskos PA, Bakeas E, Dremetsika A, Geranios A and Delakou A: (2003) "An Experimental Investigation of the Indoor Air Quality in Fifteen School Buildings in Athens, Greece", International Journal of Ventilation, 2, (3), pp185-201.

Triantafyllou AG, Zoras S, Evagelopoulos V and Garas S: (2008) "PM10, O3, CO concentrations and elemental analysis of airborne particles in a school building", Water, Arr, and Sod Pollution: Focus, 8, (1), $\mathrm{pp} 77.87$.

Wargocki P and Wyon DP: (2013) "Providing better thermal and air quality conditions in school classrooms would be cost-effective", Building and Environment, 59, pp581-589.

Weichenthal S, Dufresne A, Intante-Rivard C and Joseph L: (2008) "Characterizing and predicting ultratine particle pounts in Canadian classrooms during the winter months: Model development and evaluation", Environmental Research, 106, (3), pp349-360.

WHO, World Health Organization. "Air Quality Guidelines- Global update 2005. Particulate matter, ozone, nitrogen dioxide and sulfur dioxide", World Health Organization Regional Ottice for Europe, Copenhagen, Denmark 2005.

http://www. euro.who.int/ data/assets/pdt file/000 5/78638/E90038.pdf. Accessed 13 March 2012 
